УДК 332.1

Урбан О.А., к.е.н., доцент

Urban O. Candidate of Economic Sciences, Associate Professor https://orcid.org/0000-0002-8804-0546

Дзямулич M.I., к.е.н., доцент

Dziamulych M. Candidate of Economic Sciences, Associate Professor https://orcid.org/0000-0003-3714-5062

Чиж Н.М., к.е.н., доцент

Chyzh N. Candidate of Economic Sciences, Associate Professor https://orcid.org/0000-0002-1108-4241

\title{
ОСОБЛИВОСТІ ФУНКЦІОНУВАННЯ ФОНДОВОГО РИНКУ УКРАЇНИ В КОНТЕКСТІ СВРОІНТЕГРАЦІї
}

\author{
Луцьвкий національний технічний університет
}

\begin{abstract}
В сучасних умовах розвиток фінансових ринків є важливою складовою підвищення ефективності функціонування бізнесу, покращення інвестиційного клімату та зміцнення економіки загалом. Сучасна економіка не може функціонувати ефективно без розвиненого та стабільно працюючого фондового ринку, оскільки, за його допомогою відбувається перерозподіл вільних фінансових активів для найкращого задоволення потреб національної економіки в інвестиціях.

Сьогодні в Україні велика увага приділяється розвитку малого і середнього бізнесу, а це в свою чергу потребує додаткових фінансових ресурсів. Функціонування повноцінного фондового ринку сприяє залученню в країну дешевих довгих ресурсів, а також забезпечує створення надійної системи фінансування економічного розвитку, що в свою чергу призведе до утворення сприятливих умов для ведення бізнесу.

В статті автори проводять дослідження перспектив виходу українських компаній на фондові біржі ЄС, оскільки досить гострою є питання загального рейтингу країни і військової ситуації на Сході україни. Адже при рівних умовах української і польської компаній, акції польської компанії будуть коштувати дорожче, оскільки інвестор надає перевагу абсолютній надійності, тому очікувати на активність на фондовому ринку СС досить складно.

На сучасному етапі розвитку фондового ринку України існують такі проблемні питання, що пов'язані з розкриттям інформації, оскільки вітчизняні положення фінансової звітності розроблені на основі міжнародних стандартів, не завжди відповідають цим стандартам.

В економічній літературі відбуається гостра полеміка щодо шляхів розвитку фондового ринку України, оскільки існує два можливі шляхи ії розвязання. Перший шлях полягає в тому, що потрібно розвивати фондовий ринок «з нуля», як це, в свою чергу зробила Польща. Другий шлях передбачає імплементацію європейських стандартів завдяки поетапному впровадженню норм на фондовому ринку.

Україна має достатній економічний потенціал, щоб побудувати ефективно функціонуючий фондовий ринок. Існує два шляхи, якими може слідувати Україна: почати все «з нуля», що є досить проблематично, чи рухатись до євростандартів поступово. На сучасному етапі розвитку фондового ринку України найважливішим завданням $\epsilon$ збільшення притоку інвестицій за рахунок інтеграції ринку в світові фінансові ринки. Також не менш важливими є питання збільшення капіталізації лістингових компаній, обсягів торгів на фондовому ринку та зростання показника захисту прав інвесторів.
\end{abstract}

.Ключові слова: фондовий ринок, ичінні папери, ринок иінних паперів, міжнародний ринок иінних паперів, європейська інтеграція.

\section{PECULIARITIES OF THE FUNCTIONING OF THE STOCK MARKET OF UKRAINE IN THE CONTEXT OF EUROPEAN INTEGRATION}

\author{
Lutsk National Technical University
}

In modern conditions, the development of financial markets is an important component of improving the efficiency of business, improving the investment climate and strengthening the economy as a whole. The modern economy cannot function effectively without a developed and stable stock market, because it redistributes free financial assets to best meet the investment needs of the national economy.

Today in Ukraine much attention is paid to the development of small and medium-sized businesses, which in turn requires additional financial resources. The functioning of a full-fledged stock market helps to 
attract cheap long-term resources to the country, as well as provides a reliable system of financing economic development, which in turn will lead to the creation of favorable conditions for doing business.

In the articles, the authors provoke research into the prospects of Ukrainian companies going public on the EU stock exchanges, as the issue of the overall ranking of countries and the military situation in eastern Ukraine is acute. After all, under equal conditions of Ukrainian and Polish companies, the shares of a Polish company raise funds for traffic, if the investor prefers absolute reliability, so expect to intensify in the EU stock market.

At the current stage of development of the stock market of Ukraine, there are such problematic issues related to information disclosure, as domestic financial reporting provisions developed on the basis of international standards do not always meet these standards.

In the economic literature there is a sharp controversy about the ways of development of the stock market of Ukraine, as there are two possible ways to solve it. The first way is to develop the stock market "from scratch", as Poland has done. The second way involves the implementation of European standards through the gradual introduction of norms in the stock market.

Ukraine has sufficient economic potential to build an efficiently functioning stock market. There are two ways that Ukraine can follow: to start from scratch, which is quite problematic, or to move towards European standards gradually. At the present stage of development of the stock market of Ukraine, the most important task is to increase the inflow of investment through market integration into global financial markets. Equally important are the issues of increasing the capitalization of listed companies, trading volumes in the stock market and increasing the protection of investors' rights. integration.

Keywords: stock market, securities, securities market, international securities market, European

Постановка проблеми у загальному вигляді та іï зв'язок з важливими науковими та практичними завданнями. Акумуляція, розподіл і перерозподіл фінансових ресурсів є невід'ємними процесами розвитку сучасної економіки. У будьякій країні, з ефективно функціонуючою економікою, дані процеси відбуваються на фінансовому ринку. Важливою складовою фінансового ринку є фондовий ринок. Він відіграє суттєву роль в економіці країни, оскільки фондовий ринок є невід'ємним та важливим елементом фінансової системи ринкової економіки.

Аналізуючи фінансовий ринок загалом, було досліджено роль фондового ринку. Більшість фінансових ресурсів усіх розвинених країн світу сьогодні розміщені саме в цінних паперах. Протягом останніх років відбулись інституційні зміни структури фондових ринків, значно розширився спектр фінансових інструментів.

Для того щоб економіка країни ефективно функціонувала необхідно, щоб процес мобілізації, розподілу і перерозподілу фінансових ресурсів між іiї галузями відбувався постійно.

Актуальність даного дослідження зумовлена необхідністю вивчення механізму функціонування фондового ринку України та напрямів його розвитку, оскільки ефективне функціонування даного ринку впливає на розвиток фінансового ринку, який у свою чергу є ключовим у механізмі всієї економіки.

Аналіз останніх досліджень і публікацій, у яких започатковано вирішення даної проблеми. Питаннями дослідженням сутності фондового ринку та особливостями його функціонування цікавляться багато закордонних та вітчизняних науковців. Зокрема, теоретичні та практичні аспекти становлення та розвитку фондового ринку досліджують: О. М. Мозговий, В. А. Галанов, О. Г. Шевченко, В. М. Шелудьк, В. В. Михальський, О. О. Калюга, І. В. Краснова, Ю. Я. Кравченко, Н. І. Гавриленко, І. П. Ткаченко, О. М. Сохацька. Оскільки фондовий ринок України динамічно розвивається, то безумовно, постійно зявляються нові перспективи, проблеми, тому дослідження фондового ринку України $є$ постійно актуальним. В умовах інтеграції України в європейський економічний простір це питання набуває ще більшої цінності..

Цілі статті. Метою роботи є дослідження сучасних особливостей формування теоретичних основ та практичних аспектів функціонування фондового ринку, а також визначення перспектив інтеграції України у європейський ринок цінних паперів..

Виклад основного матеріалу дослідження 3 повним обгрунтуванням отриманих наукових результатів. 
В сучасних економічних умовах ведення бізнесу вимагає додаткових фінансових ресурсів. 3 огляду на це, перед українськими компаніями постає питання залучення додаткових інвестиційних ресурсів. Отримання коштів за допомогою банківських кредитів є дуже дорогим, а випуск облігацій є неефективним, оскільки рівень інфляції робить ринок облігацій не привабливим для іноземних інвесторів. Тому одним із найкращих шляхів вирішення проблеми залучення інвестицій є операції IPO.

Впродовж тривалого часу Варшавська біржа $є$ основним майданчиком для розміщення акцій українських компаній і кількість бажаючих розмістити свої акції саме тут постійно зростає. Якщо донедавна Варшава була інвестиційно привабливою тільки для українських аграріїв, то на сьогодні інвесторам цікаво не тільки вітчизняне сільське господарство, а й вугільна, харчова промисловість, а також енергетичні технології. За прогнозами інвестиційних аналітиків, кількість секторів української економіки, представлених на Варшавській фондовій біржі [1].

На сьогодні слід розглядати кількавагомих причин прихильності вітчизняних емітентів Варшавської фондової біржі. По-перше, в умовах недостатньо розвиненого національного фондового ринку, Варшавська фондова біржа $є$ найближчим для України світовим центром інвестицій.

По-друге, успішні історії розміщень таких компаній як Astarta i Kernel сприяли підвищенню уваги до українських цінних паперів не тільки серед польських інвесторів, але й інвесторів з інших країн, які співпрацюють з біржею. Пул інвесторів Варшавської фондової біржі на 48 \% складається з іноземних інвесторів з інших країн Свропи, Азії та США. По-третє, вимоги Варшавської фондової біржі до емітентів для розміщення значно лояльніші, ніж вимоги інших провідних світових майданчиків (LSE, Deutsche Borse, NYSE Euronext i ін.), що робить ії доступною не тільки для великих, а й середніх українських компаній, а в деяких випадках навіть для невеликих підприємств [2].

Говорячи про перспективу виходу українських компаній на фондові біржі $\mathrm{CC}$, не варто забувати про загальний рейтинг країни і про військову ситуацію на Сході. Адже при рівних умовах української і польської компаній, акції польської компанії будуть коштувати дорожче, оскільки інвестор надає перевагу абсолютній надійності, тому очікувати на активність на фондовому ринку СС не слід.

На сучасному етапі розвитку фондового ринку України існують такі проблемні питання пов'язані 3 розкриттям інформації: інвестори не завжди мають доступ до потрібної їм інформації; вітчизняні положення фінансової звітності розроблені на основі міжнародних стандартів, не завжди відповідають цим стандартам.

Фондовий ринок України, який $є$ невід'ємною частиною розвитку економіки має низку проблем, що стримують його розвиток та перешкоджають його ефективному функціонуванню. Зокрема негативно впливають на його становлення недокапіталізація, непрозорість розкриття інформації, домінування первинного ринку над вторинним, вузька номенклатура цінних паперів, що перебувають в обігу на фондовому ринку України.

Також непоширеність практики застосування IPO для залучення інвестиційних ресурсів негативно впливає на ведення бізнесу в країні. Ці проблеми негативно відображаються на динаміці розвитку фондового ринку, але варто зауважити, що вони $\epsilon$ цілком переборними.

Багато економістів стверджують, що фондовий ринок України можна розвивати двома шляхами. Перший шлях полягає в тому, що потрібно розвивати фондовий ринок «3 нуля», як це, в свою чергу зробила Польща 「3]. На фондовому ринку Польщі відразу імплементували європейські норми, які стосувалися як інфраструктури, так і правового регулювання. Ці реформи охоплювали не лише фондовий ринок, але й всю економіку. На сучасному етапі функціонування, фондовий ринок Польщі викликає довіру міжнародних інвесторів. Варто зазначити, що такі кроки були зроблені відразу, тобто фондовий ринок Польщі практично спочатку розвивався в потрібному напрямку. 
Другий шлях передбачає імплементацію європейських стандартів завдяки поетапному впровадженню норм на фондовому ринку [4, с. 29].

Цілком очевидно що перший шлях є болючішим і в результаті такого різкого застосування євростандартів багато учасників фондового ринку можуть відмовитися від своєї діяльності на ньому. Також його кардинальне реформування ризикує знищити існуючі напрацювання. Однак такий категоричний шлях реформування має право на існування.

Але, як зазначають економісти, це крайні заходи. Адже український фондовий ринок вже сформувався. Його відносить до моделі розвитку за прикладом країн континентальної Європи (Франція, Німеччина), де провідну позицію у залученні інвестицій займають боргові інструменти. В цих країнах рівень розвитку ринку акцій $\epsilon$ нижчим ніж в країнах англосаксонської моделі, де найбільшу частку в залученні інвестицій займають акції.

Вітчизняний фондовий ринок часто порівнюють 3 міжнародними, в першу чергу завдяки показникам торгівлі акціями. Але значна кількість об'єктивних факторів істотно ускладнюють розвиток в Україні ринку акцій. Наприклад, із 2013 р. по 2017 р. частка акцій у структурі торгів на фондовому ринку України зменшилася в чотири рази - з $44 \%$ до 10 \%, при цьому частка державних облігацій зросла до 43 \% [5].

Банки, які є власниками найбільших серед інших інститутів активів (1,3 трлн. грн. на початок 2020 р.), також виступають власниками найбільшого інвестиційного портфеля (135 млрд. грн.), який на 67 \% складається з державних облігацій. Відсутність уваги банків до акцій на сучасному етапі своєрідна оцінка такого інвестиційного інструменту, як акції [6].

Фондовий ринок України варто розвивати з врахуванням наявних напрацювань, на сучасному етапі боргові папери $є$ найбільш розвиненими інструментами. Тому емітенту реальніше залучити фінансові активи в Україну через облігаційні позики, а не емісію акцій.

Тобто. за проаналізованими показниками український фондовий ринок значно відстає від фондових ринків моделі до якої його відносять, рис.1.

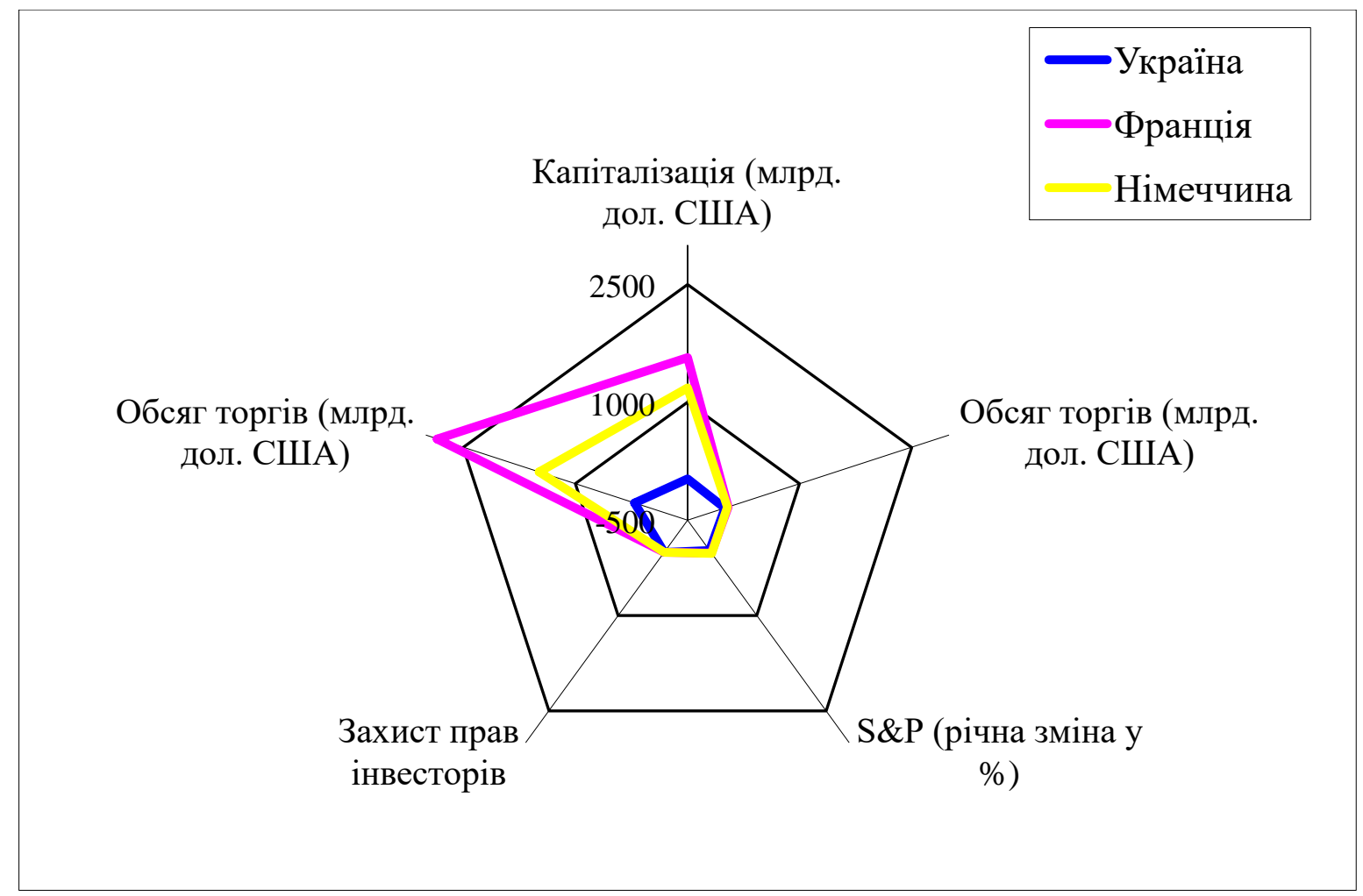

Рис. 1. Порівняння показників фондових ринків України, Франції, Німеччини 
Складено автором за [30; 80].

На сучасному етапі Україна займає низькі позиції, зокрема якщо порівнювати фондовий ринок України з фондовими ринками Франції та Німеччини (оскільки вітчизняний фондовий ринок відноситься до моделей розвитку Франції, Німеччини) (рис. 1), то можна прослідкувати, що в Україні вкрай низька капіталізація фондового ринку - 25,6 млрд. дол. США, в той час як в Франції - 1568,7 млрд. дол. США, Німеччині - 1184,5 млрд. дол. США. Також загальний обсяг торгів до ВВП в Україні лише $0,7 \%$, а в Франції - 41,9 \% та Німеччині - 34,7\%. Загальний обсяг торгів в Україні порівняно з іншими країнами є незначним, він становить лише 209,7 млрд. дол. США, в Франції - 2846,8 млрд. дол. США, Німеччині - 1484,5 млрд. дол. США. За показником захисту прав інвесторів Україна посідає 109 місце, Франція - 17, Німеччина займає 51 місце [7,8].

На рис.1 подано напрями реформування фондового ринку України і до яких стандартів потрібно прагнути. Щоб займати провідні позиції в рейтингах потрібно збільшити капіталізацію, обсяги торгів фондового ринку. Захист прав інвесторів в Україні теж не достатньо розвинений. Якщо продовжувати проводити реформи в цьому напрямку, то Україна із 109 місця може переміститися на вищі позиції.

Україна має достатній економічний потенціал, щоб побудувати ефективно функціонуючий фондовий ринок. Існує два шляхи, якими може слідувати Україна: почати все «з нуля», що є досить проблематично, чи рухатись до євростандартів поступово. На сучасному етапі розвитку фондового ринку України найважливішим завданням $є$ збільшення притоку інвестицій за рахунок інтеграції ринку в світові фінансові ринки. Також не менш важливими є питання збільшення капіталізації лістингових компаній, обсягів торгів на фондовому ринку та зростання показника захисту прав інвесторів.

Висновки. Задля формування позитивного іміджу та забезпечення стійких позицій українських компаній на фондових майданчиках країн-членів $Є С$ необхідно, в першу чергу покращити економічну ситуацію в країні. А це, в свою чергу, вимагає проведення низки реформ, які забезпечать стабільний економічний розвиток та створення сприятливого середовища для ведення бізнесу в Україні i, як наслідок, підвищення інвестиційної привабливості.

У Стратегії сталого розвитку «Україна-2030» передбачається покращення позиції України у Глобальному рейтингу конкурентоспроможності за усіма показниками; зростання ВВП на душу населення; збільшення кількості інвестицій, що призведе до збільшення попиту на акції українських компаній на фондових біржах СС.

Також потрібно більшу увагу приділяти малому і середньому підприємництву. Для сприяння розвитку малого і середнього бізнесу в Україні слід: розширити доступ до кредитних ресурсів, надати підтримку інноваційно-орієнтованим суб'єктам малого і середнього підприємництва; сприяти розвитку інфраструктури, удосконалити системи інформаційної підтримки.

Такі кроки прискорять розвиток та підвищать конкурентоспроможність малого і середнього бізнесу в Україні.

Крім європейських фондових бірж альтернативою для українських компаній по проведенню IPO можуть стати азіатські фондові майданчики. Розміщення українських компаній на азіатських фондових ринках - досить нова тенденція, вона ще не набрала обертів, але азіатський вектор може стати досить перспективним для українського бізнесу. Потужні українські холдинги готові до розміщення IPO в Азії, зокрема аргохолдинг «Ukrlandfarming» має намір провести IPO в Гонконзі.

Ефективне ведення бізнесу вимагає додаткових фінансових ресурсів. Перед українськими компаніями постає питання залучення інвестиційних ресурсів. 
Отримання коштів за допомогою банківських кредитів є дуже дорогим, а випуск облігацій $\epsilon$ неефективним, оскільки рівень інфляції робить ринок облігацій не привабливим для іноземних інвесторів. Тому одним із найкращих шляхів вирішення проблеми залучення інвестицій є операції IPO.

\section{Список бібліографічного опису:}

1. South East Europe stock markets are integrated with regional and global stock markets URL:http://mpra.ub.unimuenchen.de/44133/- (дата звернення 17.09.2020).

2. Зинчук А. Выбор площадки. Плюсы и минусы различных вариантов URL: http://www.ilfua.com/ru/publications/articles/vyborploschadki. plyusyiminusyrazlichnyhvariantov/ - (дата звернення 17.09.2019).

3. Stock Market Development in Eastern Europe. Evidence from Poland, Hungary, Russia and Ukraine URL. :file:///C:/Users/\%D0\%90\%D0\%B4\%D0\%BC\%D0\%B8\%D0\%BD\%D0\%B8\%D1\%81\%D1\%82\%D1\%80\%D0\%B0\%D1\%8 2\%D0\%BE\%D1\%80/Downloads/butsa_yuriy.pdf- (дата звернення 17.09.2019).

4. Товкун О. О. Напрями інтеграції фондового ринку України у світові ринки капіталів Екон. часоп. - XXI. - 2014. № 3/4. - C. 28-31.

5. Матеріали з офіційного сайту Національної комісії з цінних паперів та фондового ринкуURL: www.ssmsc.gov.ua(дата звернення 17.09.2020).

6. Куди податися фондовому ринку України URL:http://forbes.ua/ua/opinions/1373706-kudi-podatisya-fondovomurinku-ukrayini - (дата звернення 14.09.2020).

7. Матеріали з офіційного сайту World Bank URL:http://data.worldbank.org/indicator - (дата звернення 17.09.2020).

8. Чернявський А. Фондовий ринок України: актуальні проблеми становлення і підвищення ефективності Персонал. - 2014. - № 3/4. - С. 118-124.

\section{Reference:}

1.South East Europe stock markets are integrated with regional and global stock markets URL:http://mpra.ub.unimuenchen.de/44133/- (access date 17.09.2020).

2.Zinchuk A. Site selection. Pros and cons of different URL options: http://www.ilfua.com/ru/publications/articles/vyborploschadki. plyusyiminusyrazlichnyhvariantov / - (appeal date 17.09.2019) . [in Ukrainian]..

3.Stock Market Development in Eastern Europe. Evidence from Poland, Hungary, Russia and Ukraine URL. :file:///C:/Users/\%D0\%90\%D0\%B4\%D0\%BC\%D0\%B8\%D0\%BD\%D0\%B8\%D1\%81\%D1\%82\%D1\%80\%D0\%B0\%D1\%8 $2 \% \mathrm{D} 0 \% \mathrm{BE} \% \mathrm{D} 1 \% 80 /$ Downloads/butsa_yuriy.pdf-access date 17.09.2019).

4.Tovkun OO Directions of integration of the stock market of Ukraine in world capital markets Econ. magazine - XXI. 2014. - № 3/4. - P. 28-31 . [in Ukrainian]..

5.Materials from the official website of the National Commission on Securities and Stock MarketURL: www.ssmsc.gov.ua(access date 17.09.2020) . [in Ukrainian]..

6. Where to go to the stock market of Ukraine URL: http: //forbes.ua/ua/opinions/1373706-kudi-podatisya-fondovomu-rinkuukrayini - (appeal date 14.09.2020) . [in Ukrainian]..

7.Materials from the official website of the World Bank URL: http://data.worldbank.org/indicator - (access date 17.09.2020). 8.Chernyavsky A. The stock market of Ukraine: current issues of formation and efficiency Staff. - 2014. - № 3/4. - P. 118124 . [in Ukrainian].

Дата подання публікації 07.04.2021p. 